\title{
Surviving in a warmer world: environmental and genetic responses
}

\author{
A. Donnelly ${ }^{1,9, *}$, A. Caffarra ${ }^{2,10}$, C. T. Kelleher ${ }^{3}$, B. F. O'Neill $^{1}$, E. Diskin ${ }^{1}$, A. Pletsers ${ }^{1}$, \\ H. Proctor ${ }^{1}$, R. Stirnemann ${ }^{1}$, J. O'Halloran ${ }^{4}$, J. Peñuelas ${ }^{5}$, T. R. Hodkinson ${ }^{1}$, T. H. Sparks ${ }^{6,7,8}$ \\ ${ }^{1}$ School of Natural Sciences, Trinity College Dublin, Ireland \\ ${ }^{2}$ Department of Agroecosystems and Sustainable Bioresources, Research and Innovation Centre, Fondazione E. Mach, \\ 38010 San Michele all'Adige, Trento, Italy \\ ${ }^{3}$ Herbarium, National Botanic Gardens, Glasnevin, Dublin 9, Ireland \\ ${ }^{4}$ School of Biological, Earth and Environmental Sciences, Enterprise Centre, Distillery Fields, University College Cork, Ireland \\ ${ }^{5}$ Global Ecology Unit CREAF-CEAB-CSIC, Center for Ecological Research and Forestry Applications, Facultat de Ciències, \\ Campus Universitat Autònoma de Barcelona, 08193 Bellaterra, Barcelona, Spain \\ ${ }^{6}$ Fachgebiet für Ökoklimatologie, Technische Universität München, Hans-Carl-von-Carlowitz-Platz 2, 85354 Freising, Germany \\ ${ }^{7}$ Institute of Zoology, Pozna University of Life Sciences, Wojska Polskiego 71C, 60-625 Pozna, Poland \\ ${ }^{8}$ Department of Zoology, University of Cambridge, Downing Street, Cambridge CB2 3EJ, UK \\ ${ }^{9}$ Present address: Department of Geography, University of Wisconsin-Milwaukee, Wisconsin 53201, USA \\ ${ }^{10}$ Present address: Centre de Recherche de Climatologie - UMR Biogéosciences, Université de Bourgogne, 21000 Dijon, France
}

\begin{abstract}
There are numerous reports in the literature of advancing trends in phenophases of plants, insects and birds attributed to rising temperature resulting from human-driven climate warming. One mechanism that enables a population to respond rapidly to changes in the environment is termed phenotypic plasticity. This plasticity grants a degree of flexibility to enable the timing of developmental stages to coincide with resource availability. If, however, environmental conditions exceed the plastic limits of an organism, evolutionary change may be necessary in order to ensure continued survival of their populations. We review evidence for phenotypic plasticity and genetic adaptation in phenological characteristics associated with climatic warming. We focus this review on examples from trees, insects and birds. We found many reports of direct observations of phenotypic plasticity but fewer studies providing conclusive evidence of genetic adaptation. Evidence for changes in genes linked with adaptive traits associated with a warming climate was stronger in insects, that have a relatively short life-cycle, than in longer-lived birds and trees. Further research is required to identify both appropriate long-term data sets for a range of species and traits and suitable analytical methods, which will permit the study of the complex interaction between phenotypic plasticity and genetic adaptation of organisms and their populations in response to climatic change.
\end{abstract}

KEY WORDS: Climate change $\cdot$ Phenotypic plasticity $\cdot$ Genetic adaptation $\cdot$ Trees $\cdot$ Insects $\cdot$ Birds

\section{INTRODUCTION}

Phenological studies relating to recent climate warming have traditionally focused on examining trends in the timing of key phenophases and relating these to climate variables (Ahas 1999, Roy \& Sparks 2000, Peñuelas et al. 2002, Dose \& Menzel 2004,
Menzel et al. 2006, Donnelly et al. 2009). Rutishauser et al. (2009) compared plant phenology records in relation to temperature in Switzerland and the UK over 2 centuries (1750s to 1950s) and concluded that the well documented advance in spring phenology in the 1980s was unprecedented because they found no evidence of a synchronous change-point in phenological 

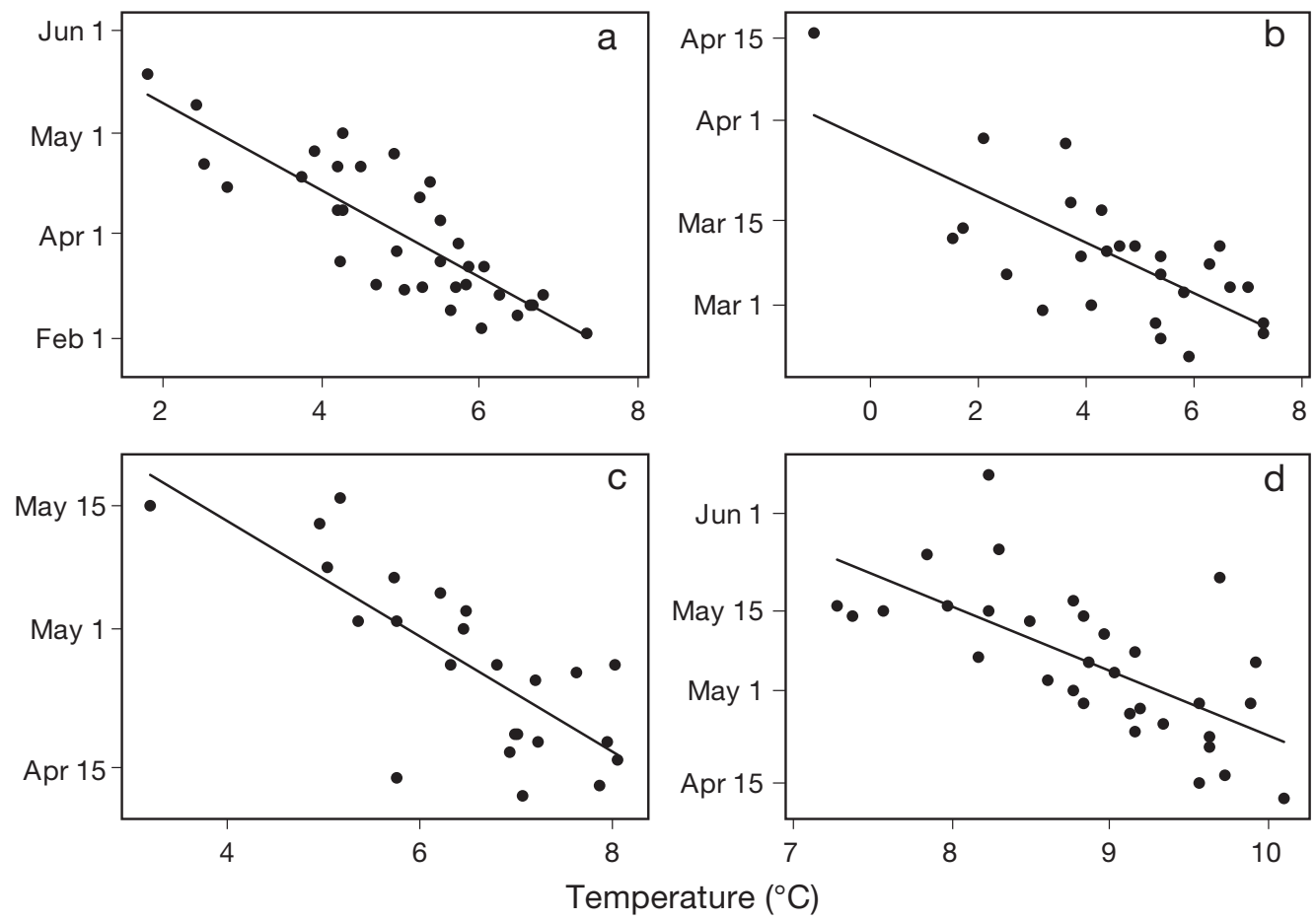

Fig. 1. Examples of phenological response to temperature: (a) first flowering date of blackthorn Prunus spinosa to mean JanMar temperature (slope $=-13.1$ $\pm 1.5, R^{2}=69.6, \mathrm{n}=34$ ), (b) first spawning date of common frog Rana temporaria to mean Feb temperature (slope $=-4.2 \pm 0.8$, $\mathrm{R}^{2}=51.4, \mathrm{n}=26$ ), (c) first leafing date of pedunculate oak Quercus robur to mean Feb-Apr temperature (slope $=-6.6 \pm 1.2$, $\mathrm{R}^{2}=58.4, \mathrm{n}=24$ ), (d) first appearance date of orange tip butterfly Anthocharis cardamines to mean Mar-May temperature (slope $=-11.3 \pm 2.3, \mathrm{R}^{2}=44.8, \mathrm{n}=$ 32). Linear regression lines superimposed; all $\mathrm{p}<0.001$. Data recorded by A. Phillips in Walsall, UK, in 1976-2009, provided courtesy of the UK Phenology Network. All temperatures are from the Central England series. Both vertical and horizontal scales vary

records at the 2 sites over the study period (which predated the 1980s). Fig. 1 presents 4 examples of the temperature-phenophase relationship, which clearly shows that the phenology of the trees (Prunus and Quercus), frog (Rana) and butterfly (Anthocharis) advanced when spring temperature increased. Whereas these responses have proven useful as indicators of climate warming, the potential for organisms to adapt genetically to a changing environment has received less attention (Bearhop et al. 2005, Jonzén et al. 2006, Sparks \& Tryjanowski 2007).

Different environments may induce a plastic response in behavioural, morphological, developmental and physiological characteristics in an individual (Price et al. 2003, Pigliucci et al. 2006, Fonti et al. 2010). In response to such pressures, phenotypic plasticity enables an organism to alter the timing of its developmental stages (Bradshaw 1965) without altering its genetic composition. Fig. 2, for example, illustrates that flowering date is later in more northern than southern latitudes demonstrating a degree of plasticity in this characteristic in response to temperature. Beyond these temperature limits, imposed by genetic composition, flowering will not take place. Phenotypic plasticity is generally a shorter-term response than genetic adaptation depending on the species in question (Sánchez-Vargas et al. 2007) and ensures the continued survival of organisms in a changing environment. For example, it enables plants and animals to respond to seasonal changes in temperature and allows birds and insects to modify their behaviour in response to environmental variation during migration (Hüppop \& Hüppop 2003, Vähätalo et al. 2004). However, if the range of

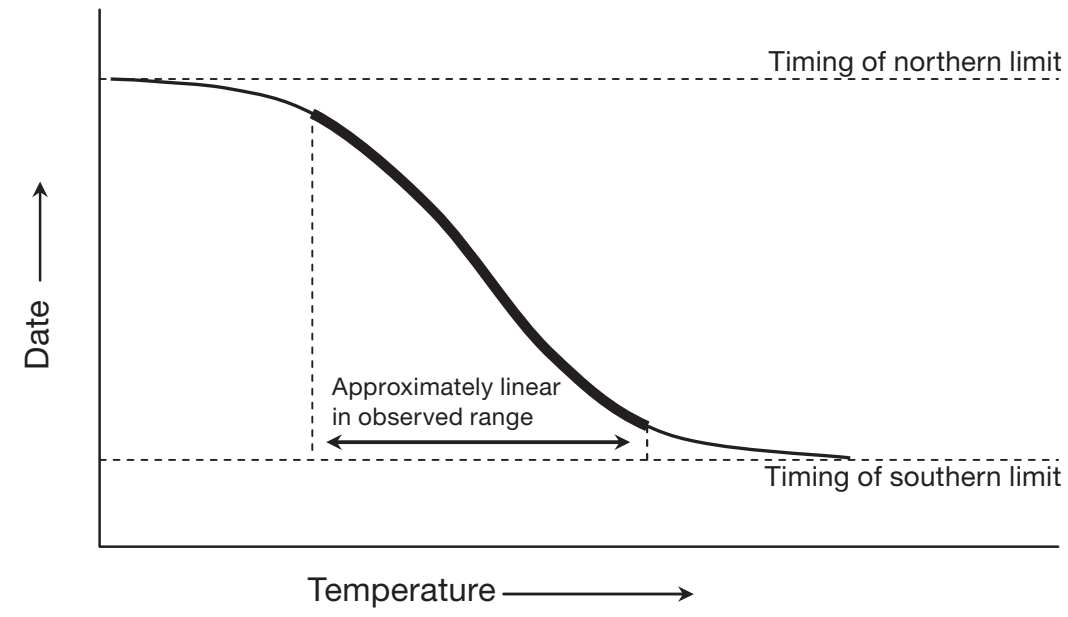

Fig. 2. Hypothesised relationship between flowering date and temperature, where extreme dates are probably observed at latitudinal extremes of a species range. Adapted from Sparks et al. (2000) 
environmental conditions exceeds the plastic limits (of a particular trait) of an organism, there may be increased selective pressure at a population level for genetic adaptation in that trait (Gienapp et al. 2008). Furthermore, the nature of the plastic response of populations is also under selective pressure and this is not necessarily directional. Therefore, plasticity interacts with environmental conditions in a complex way to influence genetic change (Price et al. 2003, Pigliucci et al. 2006). Fig. 3 illustrates how a stable rise in temperature may initially induce a phenotypically plastic response in the timing of flowering in a tree population, which may ultimately lead to a genetic change through natural selection in favour of earlier flowering trees.

In contrast to phenotypic plasticity, genetic adaptation arises out of selection of favourable traits in populations. Climate change has been shown to directly influence heritable genetic changes in birds, insects and other animals (Bradshaw \& Holzapfel 2006, Karell et al. 2011). The predicted spatial and temporal heterogeneity in patterns of climate change will correspond to similarly heterogeneous selection pressures (Jonzén et al. 2007). Species with a specialized ecology and a narrow geographical range are also vulnerable to changes that could alter their habitat. For such species, survival will depend on a fast rate of genetic adaptation at the population level and/or a high degree of phenotypic plasticity.

The aim of this review was to investigate if and how a number of species in a number of different taxa are responding to recent climate warming. We chose to examine the literature for evidence of 2 mechanisms that operate at different timescales, depending on the species in question, but which both allow species to survive in a changing environment: phenotypic plasticity and genetic adaptation. Furthermore, we aimed to determine if specific examples of genetic adaptation attributable to climate warming were available across a range of short- and long-lived species and to test the hypothesis that species cannot adequately respond to climate warming by means of phenotypic plasticity alone.

In order to keep the review focused, we identified 3 representative groups of organisms, namely trees, insects and birds, which encompass a range of trophic levels. Well-documented phenotypically plastic responses to warming found in other groups, such as herbaceous plants (Fitter \& Fitter 2002, Dunne et al. 2003), mammals (Inouye et al. 2000, Post \& Forchhammer 2008, Monteith et al. 2011, Moyes et al. 2011) and fish (Beebee 1995, Sims et al. 2004, Genner et al. 2010) are dealt with elsewhere in the literature. Climate change will undoubtedly have a variety of impacts on a wide range of taxa, but we felt it appropriate to concentrate on the 3 chosen groups.

\section{EVIDENCE OF PHENOTYPIC RESPONSES}

\subsection{Timing of leafing in trees}

Shifts in plant phenology and species' ranges in response to changing temperature have been widely reported (Chmielewski \& Rötzer 2001, Parmesan 2006, Cleland et al. 2007, Peñuelas et al. 2007). Trees are under selective pressure from a range of climate change variables, such as rising temperatures, changes in precipitation patterns and increasing frequency of extreme weather events. Because trees are
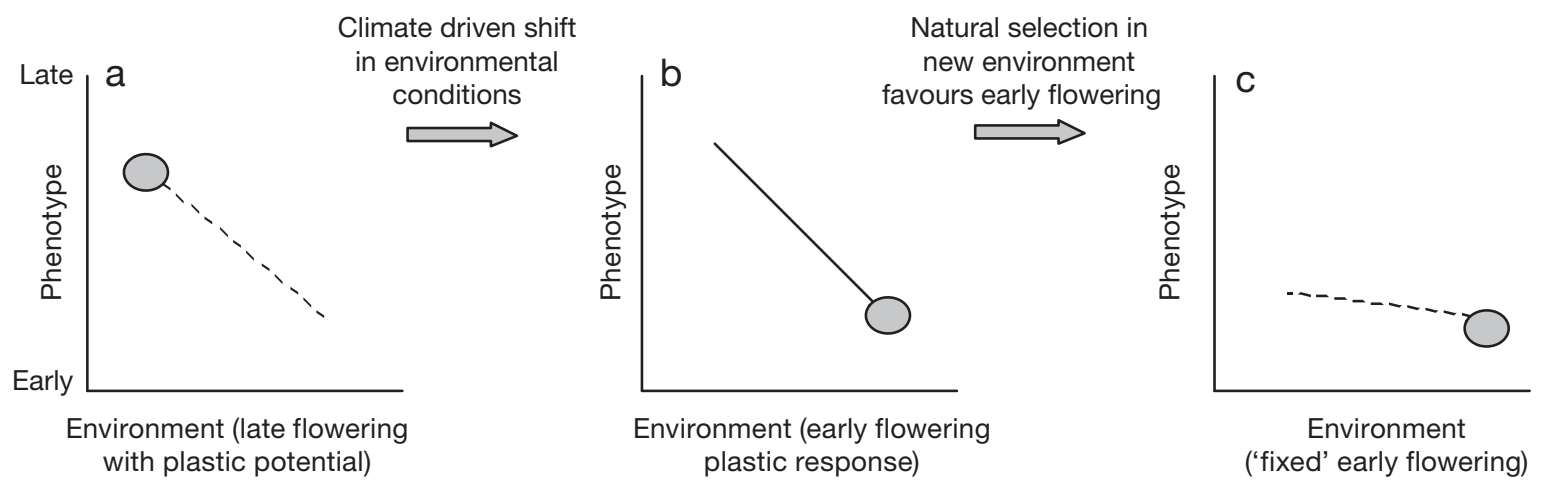

Fig. 3. Effect of genetic adaptation on a phenotypically plastic characteristic in response to a permanent change in environmental condition. Population of trees (circles) exhibit (a) late flowering in the current environment but if environmental conditions change such that temperature rises, there is potential for early flowering to occur; (b) a new earlier flowering phenotype results from phenotypic plasticity with no genetic change and (c) subsequently natural selection may genetically 'fix' the earlier flowering phenotype in the new stable warmer environment, assuming there will be no regular late frosts. Adapted from Pigliucci et al. (2006) 
both sessile and long-lived and, unlike many animals, cannot easily migrate to a suitable habitat, individuals must respond to environmental variations through phenotypic plasticity. The type of phenotypic response will vary depending on the type of pressure. Gradual changes such as slowly rising temperatures are likely to cause increases in metabolic rate and/or advances in phenological events. In contrast, the occurrence of extreme events is likely to cause a sudden response involving survival and recovery mechanisms (Gutschick \& BassiriRad 2003). For example, the ability to survive strong winds depends on the ability to withstand mechanical stress (survival mechanism) and regenerate damaged tissues (recovery mechanism). Similarly, the survival in extremely warm climatic conditions depends on the ability to readily synthesise heat shock proteins, reduce evapotranspiration and to recover from damage afterwards (Bradshaw 1972, Mc Dowell et al. 2008). However on a broader timescale, tree populations can respond to changing conditions by migrating to more suitable ecological niches. If they fail to do this, they may face extinction (Aitken et al. 2008).

Recent phenotypic responses are well documented in studies of tree phenology across Europe (Menzel 2000, Menzel et al. 2001, 2006, Chmielewski \& Rötzer 2001, Donnelly et al. 2006, Vitasse et al. 2010). Tree species are responding to warmer spring temperatures by advancing the timing of bud burst (Schleip et al. 2008, 2009a,b). The critical nature of this timing is illustrated, for example, in studies on Fagus sylvatica, which have shown that early bud burst coinciding with late frost episodes leads to leaf injury and subsequent reduced growth (Kreyling et al. 2011). Some studies have presented evidence of an inadequate ability of tree populations to genetically adapt fast enough to climate warming (Jump et al. 2006a, Aitken et al. 2008, Peñuelas et al. 2008, 2011), but other studies on bud burst timing have shown that trees possess sufficient phenotypic plasticity to enable them to cope with climatic variations and capitalize on earlier spring warming by extending their growing season (Schleip et al. 2009b, Vitasse et al. 2010). For example, Vitasse et al. (2010) showed that beech (Fagus) and oak (Quercus) trees of different provenances grown in common gardens along an altitudinal gradient displayed a high level of phenotypic plasticity with the timing of leaf unfolding advancing by an average of $5.7 \mathrm{~d}$ with every $1{ }^{\circ} \mathrm{C}$ rise in temperature. This pronounced plastic response should enable such species to respond to rapidly increasing temperatures (Vitasse et al. 2010). Previous studies
(Kramer 1995) compared spring phenophases of genotypically homogenous clones of different tree species grown at various European sites (International Phenological Gardens) and found that the variation in their phenological response was comparable to that of heterogeneous local populations. This illustrated that levels of variation in individuals were similar to variation that is expected in the outbred population as a whole. This finding implies that plasticity might account for most of the variation observed in plant phenology, and suggests that at least some responses to environmental triggers, are so plastic that they have not been subject to local selection in tree populations.

These studies, and the fact that long-lived trees are capable of advancing or delaying their phenophases to remain synchronized with local weather conditions, suggests that the timing of bud burst is a highly plastic trait, controlled by temperature. However, there is a lack of understanding of its limits and of any underlying variation in the genes controlling it. Vitasse et al. (2010) demonstrated a potential limit to the plastic response in leaf unfolding dates and highlighted the importance of the interaction between variables affecting the response. In their study, the growing season was extended in response to a rise in temperature of up to $10^{\circ} \mathrm{C}$ but was shortened above this threshold. Similarly for European oak, Morin et al. (2010) showed a deceleration in the rate of leaf unfolding advance as temperatures increased. Furthermore, Sparks et al. (2000) suggested a similar pattern for flowering date (Fig. 2). These non-linear responses in spring phenology to environmental conditions, and the interaction between multiple factors (such as temperature and photoperiod) must be taken into account when developing predictive models of phenology (Körner \& Basler 2010, Morin et al. 2010, Caffarra et al. 2011).

The evidence presented above suggests a limit to the phenotypic plasticity that affords trees the ability to respond to rising temperatures. Whereas some responses, such as the relationship between bud development and temperature in fully chilled tree seedlings, have been clearly described (Sarvas 1974, Cannell \& Smith 1983, Caffarra \& Donnelly 2011), many more require clarification, especially those involving interactions between multiple factors. For example, the phenological response to temperature depends on factors such as (1) the particular stage in the life-cycle of the plant, (2) photoperiod, (3) previous events during the growing season (Heide 2003), and (4) the age of the plant (Augspurger \& Bartlett 2003). In addition, the response to temperature ap- 
pears to be more pronounced in the case of spring phenophases than summer phenophases (Schleip et al. 2009b). Given these inconclusive reports, it would be useful to perform more experimental studies to model the reaction norms of tree phenology to a range of environmental factors and their interactions. A more detailed knowledge of these responses is crucial in order to disentangle phenotypically plastic responses from genetic adaptations to climate change.

\subsection{Insect phenophases}

Recent climate warming has been cited as the driving force behind the advancement of phenological events in insects, including the timing of first appearance of bees (Gordo \& Sanz 2005, Sparks et al. 2010), butterflies and moths (Stefanescu et al. 2003, Altermatt 2010, Westwood \& Blair 2010), aphids (Zhou et al. 1995, Harrington et al. 2007), hoverflies (Morris 2000) and dragonflies and damselflies (Hassall et al. 2007, Dingemanse \& Kalkman 2008). Phenotypic plasticity in thermal dependence allows herbivores and pollinators to closely match the phenology of their host plants that may also have advanced phenophases with climatic warming (van Asch \& Visser 2007, Hegland et al. 2009).

While the timing of first appearance is often the most recorded phenophase in insects, other phenophases are also affected by climatic warming. Many species of insects migrate, both short and long distances, and often vertically (i.e. to different altitudes). As such, the timing of migration can be a useful phenophase to consider in climate change studies. Aphid species, in particular, frequently exhibit short distance migratory flights from a primary host (on which the aphids often overwinter) to a secondary host. Many aphid species in the UK have shown an advance in migration times between hosts over the last $30 \mathrm{yr}$ in response to increasing temperatures (Zhou et al. 1995, Harrington et al. 2007). Several aphid species do not, however, show an advance in first appearance over the same time period, demonstrating the importance of considering a range of phenophases to determine the effects of climate warming as some may be more plastic than others (Hullé et al. 2010).

Adaptive change in one phenophase may adversely affect subsequent phenophases. Doi (2008) found that spring emergence of dragonflies in Japan has come later with increasing temperatures over time. This change was thought to be the result of a shift of the second generation of this bivoltine species, with active periods later in the autumn resulting in a delay in winter diapause and subsequent delay in spring emergence. This later spring emergence may lead to mismatches with food source phenology. Last appearance dates and length of flight season are also important parameters to observe for change and plasticity, particularly in multivoltine species. These species have fast developmental rates thus allowing existence of multiple generations each year. The number of generations per year is usually plastic, dependent on resource availability and temperature (Scoble 1995). Climate warming can contribute to faster development, shorter generation times, and increased numbers of generations per year in multivoltine species, which can prolong the flight period and result in a later last appearance date (Altermatt 2010, MartínVertedor et al. 2010).

An analysis of phenology of the European grapevine moth Lobesia botrana in Spain over the last $20 \mathrm{yr}$ found advancement in the timing of first appearance and an increase in the number of generations per year coupled with an extended flight season (MartínVertedor et al. 2010). A wider analysis of flight periods of multivoltine European moth species found that the number of generations per year, and consequently flight periods, have significantly increased over the last $150 \mathrm{yr}$, particularly since the 1980s (Altermatt 2010). An increase in the number of generations per year and periods of activity are particularly important with regard to agricultural pests, and consequently, several phenological models have been developed to try to predict periods of activity (Kocmánková et al. 2010, Luedeling et al. 2011). For example, a phenological model of multiple pests (codling moth Cydia pomonella, navel orangeworm Amyelois transitella, two-spotted spider mite Tetranychus urticae, and European red mite Panonychus ulmi) of walnut in California predicted that the number of generations per year of all of the species modeled would increase with increasing temperatures (Luedeling et al. 2011). A similar model of multiple pests (European corn borer Ostrinia nubilalis and Colorado potato beetle Leptinotarsa decemlineata) in central Europe also found increased numbers of generations per year with temperature increases (Kocmánková et al. 2010). While the pest pressure is predicted to increase in both of these systems with climate change, both sets of authors admit that neither of the models include information on winter diapause requirements, and that more research is necessary to improve model predications. 


\subsection{Bird phenology}

\subsubsection{Arrival time of migratory birds}

In terms of adjusting to climate change, phenotypic plasticity in birds may involve changes in diet, habitat selection and migratory behaviour (Dunn \& Winkler 2010). Migratory birds are particularly vulnerable to warming as their annual life cycle involves breeding, moult and 2 migration events (Pulido et al. 2001), all of which are influenced by temperature. In general, migratory birds respond to rising spring temperature by arriving earlier at their breeding grounds (Hüppop \& Hüppop 2003, Sparks et al. 2005, Donnelly et al. 2009, Lehikoinen \& Sparks 2010, Saino et al. 2010) and by laying their eggs earlier (Both \& Visser 2001, Both et al. 2006), thus increasing their potential for sustained synchronization with their food source (caterpillars and other insects) and subsequent breeding success. The advance in the timing of arrival has been shown to be greater for earlier migrating species than later migrating species (Sparks et al. 2005, Lehikoinen \& Sparks 2010). However, not all species respond to rising temperature in the same way. For example, a long distance bird species, the willow warbler Phylloscopus trochilus, has been shown to arrive later at their breeding grounds in response to increasing temperature (Barrett 2002, Peñuelas et al. 2002).

Short-distance migrants are able to respond relatively quickly to environmental changes at the breeding grounds but long distance migrants may be constrained in their plastic responses by endogenous rhythms that control migration, as migration onset is unlikely to be directly linked to climate at the breeding ground (Visser et al. 1998, Cotton 2003, Lehikoinen et al. 2004, Jonzén et al. 2006, Pulido 2007, Lehikoinen \& Sparks 2010, Saino et al. 2010, Tøttrup et al. 2010). However, recent research proposed that trans-Saharan migrant birds may be able to gauge climatic conditions in the breeding grounds if meteorological conditions in Europe (during the breeding season) co-vary with those in Africa (during late winter) and thus respond phenotypically by adjusting their migration to optimise arrival time (Saino \& Ambrosini 2008). Indeed, teleconnections between large-scale climate systems such as the El Niño Southern Oscillation (ENSO) and the North Atlantic Oscillation (NAO) have been reported (e.g. Hurrell \& Trenberth 2010).

Migration timing may also be influenced by habitat development rates in spring, as different habitats respond differently to climate change, thus potentially impacting food availability for arriving migrants (Lehikoinen \& Sparks 2010). A study of a range of migrants in North America during the last century revealed that grassland species advanced more than scrubland species while forest species showed little advance (Butler 2003), suggesting that habitat type and timing of arrival are strongly correlated.

Earlier arrival at a breeding ground has consequences for the timing of breeding and (where appropriate) the number of broods produced by migratory birds. A significant advance in laying date in response to warming has been reported for a range of bird species at a range of locations (Dunn \& Winkler 2010). Both \& te Marvelde (2007) compared geographical variation in egg-laying dates of a short distance (European starling Sturnus vulgaris) and a long distance (pied flycatcher Ficedula hypoleuca) migrant over a 25 yr period in Europe. They reported that the rate of temperature increase varied over geographical area and over the spring season and that this resulted in spatial and temporal heterogeneity in egg-laying dates across Europe. The long-distance bird migrated later in the season than its short-distance counterpart and travelled over a larger geographical area, thus exposing the birds to a wider range of temperature changes. Due to differing rates of warming, northern populations of the pied flycatcher experienced more warming during migration than southern populations; therefore, conditions along the migration routes appear to vary over space and time, with migration and egg-laying dates varying accordingly. As a result, the phenological response to environmental change within a species may differ at different locations.

\subsubsection{Egg-laying times of resident birds}

A study in the UK by Charmantier et al. (2008) showed that, over a $47 \mathrm{yr}$ period, the egg-laying dates of a resident great tit Parus major population advanced, by $2 \mathrm{wk}$, in tandem with availability of a key food source: the winter moth Operoptera brumata. The authors reported a strong correlation between these events and increasing spring temperature and concluded that changing environmental conditions resulted in a phenotypic response alone, with no evidence of changes in the plastic response itself. More recently Matthysen et al. (2011) found a similar pattern of advancing egg-laying date for both blue tits Cyanistes caeruleus and great tits in Belgium. 
However, this was not found to be the case for a similar population of birds in the Netherlands. Visser et al. (1998) reported no advance in the egg-laying date of resident great tits over a 23 yr period, even though spring temperature increased, and both leaf and caterpillar emergence occurred earlier. Both (2010) suggested a genetic component might also help explain the different responses between the 2 populations, such that the Dutch population showed some degree of genetic variation for reaction norms of laying date on temperature whereas the UK population did not.

If interdependent species respond to climate warming at the same rate, such as in the case of the great tits and their caterpillar prey in the UK (Charmantier et al. 2008) and Belgium (Matthysen et al. 2011), synchrony will be maintained in the future. However, climate warming has the potential to disrupt existing phenological synchronies as in the case of great tits and winter moth caterpillars in the Netherlands (Visser et al. 1998). In addition, Both et al. (2005) reported a mismatch between arrival time of the pied flycatcher and their main food source. The resulting mismatches across trophic levels can have severe negative consequences, and even threaten population viability (Nussey et al. 2005). However, other competitors may flourish if they are able to keep pace with their food source. The evidence from both migrant and resident birds suggests that phenotypically plastic responses to warming are an important mechanism that enables birds to respond to a changing environment. But the limits of this mechanism remain to be tested.

\section{EVIDENCE OF EVOLUTIONARY RESPONSE}

\subsection{Genetic variation in trees across climatic gradients}

The evolutionary response of plants to climatic gradients is clearly shown in studies of adaptation in local populations of different tree species across Eurasia (Savolainen et al. 2007). For example, aspen Populus tremula is distributed from the Mediterranean to the Subarctic, and across a broad longitudinal range from the European Atlantic coast inland to Russia (Jalas \& Suominen 1976). Local populations of such species are genetically adapted to their specific growing conditions (Hall et al. 2007, Savolainen et al. 2007, Dounavi et al. 2010). Genetic adaptations of local populations to climate have been shown for several tree species through provenance testing
(Savolainen et al. 2007, Aitken et al. 2008) whereby plants/seeds collected from a variety of locations are grown under common conditions in order to assess their performance. Plant species may be capable of surviving outside their normal range but are prevented from establishing populations because of several factors such as competition and pre- or postzygotic breeding barriers (Thomasset et al. 2011). This is clearly demonstrated by the fact that a species from a specific climatic zone is capable of survival and may often thrive when grown in different botanic gardens with a range of contrasting environmental conditions.

Some climatic-related genetic adaptations in specific populations have been recorded. In the case of aspen, a common garden study of Swedish populations found that trees from lower latitudes flushed earlier than ones from higher latitudes (Hall et al. 2007). A similar study on pine bud set across a latitudinal gradient from Spain to Finland showed that the timing of bud set was determined by the geographic origin of the plant rather than the conditions of growth in the study sites (García-Gil et al. 2003). In these cases, differences in phenological response among populations were primarily determined by genetic adaptation of the source populations to local conditions from which they were collected. Adaptive differentiation of populations in temperate and boreal forests persists despite the homogenizing action of gene-flow (Savolainen et al. 2007). In addition to this, co-occurring tree species can also show considerable inter-specific variation in their response to the environment in which they are growing (Lechowicz 1984, Ogaya \& Peñuelas 2007). For example, in a drought experiment on a Mediterranean holm oak forest, the dominant tree species varied in biomass production. Under drought conditions, Arbutus unedo and Quercus ilex showed a sharp reduction in biomass whereas Phillyrea latifolia appeared to be insensitive to drought in terms of biomass production (Ogaya \& Peñuelas 2007).

Other studies have highlighted a strong heritable component in phenology-related traits such as bud set and bud burst (Bradshaw \& Stettler 1995, Yakovlev et al. 2006). Bradshaw \& Stettler (1995) mapped regions of the poplar genome responsible for phenology of leaf flushing in an $\mathrm{F}_{2}$ generation derived from a cross between Populus deltoides (Eastern cottonwood) and $P$. trichocarpa (Black cottonwood). They identified 5 quantitative trait loci (QTLs) of large effect that were responsible for a large proportion of genetic variation in the timing of spring leaf flush. They did not however, investigate a broad range of 
poplars across a climatic gradient to see how the QTLs varied with climatic factors.

In addition to these common garden and genetic mapping studies, some authors suggest that epigenetic factors may be influencing the timing of particular phenophases of trees (Johnsen et al. 2005, Yakovlev et al. 2006, 2011). Yakovlev et al. (2006, 2011) suggested that epigenetic effects may be involved in the timing of bud phenology in Norway spruce. Epigenetic effects are a result of heritable traits that are brought about without change in the primary sequence of the DNA. They involve some other modification of the DNA, such as methylation, which alters expression of the genes. Norway spruce Picea abies adjusts its phenotype by an epigenetic response mechanism that is calibrated by the temperature conditions it experiences during embryo development. The warmer the temperature during embryogenesis the later the resulting plants formed terminal buds in a common environment, suggesting a genetic basis governing this epigenetic mechanism. Expression studies to identify the genes and other regulatory elements responsible in epigenetic regulation of the growth-dormancy cycle indicated that micro-RNAs are potentially important factors in the regulation of bud phenology (Schleip et al. 2008, Yakovlev et al. 2011). In this study, Yakovlev et al. (2011) identified many novel candidate genes involved in tree phenology, but further work remains to be carried out to identify and characterize these targeted genes to better understand the epigenetic regulation of the growth-dormancy cycle.

\subsection{Response to recent climate warming: adaptation and genetic variation}

Recent climate change relates to a time-scale spanning only decades. It is important to know whether or not plant species can respond genetically to the current rapid change in climatic conditions and, if so, how fast they can do this (Hodkinson 2011). In comparison to insects and birds, plants have a more limited capacity to migrate when environmental conditions change rapidly. Potential outcomes of climate change on plant populations depend on their ability to respond, which, in turn, depends on phenotypic plasticity, underlying genetic variation, dispersal ability and establishment rates (Savolainen et al. 2007). As trees are long-lived sedentary organisms, they must withstand considerable variation in environmental conditions over their lifespan. Historical records from the recent past have provided evidence of rapid acclimation in the timing of phenological events across Europe such as earlier bud burst and flowering times in response to increases in spring temperatures (Menzel et al. 2006). In addition, since a species can be distributed over a large geographical range, each population must acclimate to local conditions to ensure survival. Therefore, there must be a balance between genetic adaptation to specific local environmental conditions that will confer a selective advantage at that site and time, and phenotypic plasticity that allows for flexibility in the face of a changing environment.

Some studies have shown genetic variation associated with climate and phenology, but evidence for an evolutionary response to climate change remains scarce (Jump \& Peñuelas 2005, Jump et al. 2006b, 2008). For example, Jump et al. (2006b) showed allele frequency variation of $0.135^{\circ} \mathrm{C}^{-1}$ when assessing variation in populations of Fagus sylvatica across an altitudinal gradient. It is reasonable to expect that, due to their longevity and the length of breeding cycles, trees will be one of the last functional groups to show climate-driven evolutionary changes. In particular, the rate at which they will be able to genetically adapt will depend on the length of time it takes to reach maturity. Whereas tree species that are able to produce seeds after a few years (e.g. willows) have fast regeneration times and a potential for fast evolutionary change, tree species that reach reproductive age after decades (e.g. oaks) will not be able to adapt to climate change within the short-term. Among the studies investigating climate-driven genetic variation, some have focused on variation in phenologyrelated genes in wild-plant populations across broad geographic ranges (García-Gil et al. 2003, Ingvarsson et al. 2006, Savolainen \& Pyhäjärvi 2007, Savolainen et al. 2007). These studies aimed to identify selection pressure on genes in wild populations and to provide associations of gene variants and phenotypes with climatic pressures. Association studies are studies that attempt to identify the causal gene variants or genetic markers linked to phenotypic variation. They are commonly used in human genetic studies on disease where extensive research has led to the development of novel technologies, but they are a relatively new method in forest tree genetics. However, it is expected that they will become useful in determining the mechanisms of complex traits and provide an understanding of the interaction between genotype and phenotype (Neale \& Savolainen 2004). A study carried out on aspen in Europe showed significant latitudinal variation in phytochrome B2 (phyB2), a gene involved in the control of light res- 
ponse and photoperiodism in plants (Ingvarsson et al. 2006). However, such variation was not found in a homolog of phyB2 in Scots pine Pinus sylvestris populations across Europe (García-Gil et al. 2003). An experimental translocation of larch Larix europaea and pine $P$. mugo along an altitudinal gradient revealed differences in genetic diversity of specific loci corresponding to this gradient (Müller-Starck et al. 2010). The results showed that $10 \mathrm{yr}$ after translocation, differences in genetic richness and genetic diversity were evident when the initial and final material were compared. These data could be indicative of variation relating to phenological responses. However, a more recent study on candidate genes involved in bud burst in oak (Quercus spp.) populations growing in a common garden experiment showed no significant genetic variation associated with timing of bud burst (Derory et al. 2010). These inconsistencies require further investigation to help understand the genetic variation underlying phenological responses. To date, most studies have used a small sample size or a restricted geographical distribution; therefore, extrapolation of the results to different species or to larger areas is not advisable. Further studies will be key to identifying naturalselection pressures resulting from current and future climate change, firstly, to establish the potential inherent in species and secondly, to assess if climate change results in selection of favoured variants.

\subsection{Evolutionary responses in insects}

Several studies have assessed how terrestrial and aquatic insects may respond phenotypically to future climate warming (Guo et al. 2009, Musolin 2009). Studies with the terrestrial multivoltine southern green stink bug Nezara viridula in Japan demonstrated that increased temperatures advanced phenology, development and increased winter survival (Musolin 2009). These studies also found that increased summer temperatures adversely affected the summer generation, which may have long-term implications for other subsequent generations throughout the year and population genetics (Musolin 2009). Guo et al. (2009) used artificial warming experiments in the grasslands of Mongolia and found that phenology advanced in 3 species of grasshopper (Chorthippus fallax, Dasyhippus barbipes and Oedaleus asiaticus) that currently do not overlap temporally. The degree of advancement differed among species, resulting in increased temporal overlap of the 3 species under warming conditions. Thus they predicted in- creased competition among the species, which would influence fitness and hence, result in an adaptive evolutionary response (Guo et al. 2009). There are fewer examples for aquatic insects. Studies have been undertaken with cold-water aquatic insects; these have generally found that these species perform worse under elevated temperature and related climate change conditions (e.g. Ferreira et al. 2010). It is possible that they may have difficulty adapting to rapid climate warming, as they generally have a lower thermal tolerance, but more research is required.

Much of the empirical evidence for population changes in gene frequencies in response to climate change in insects comes from pomace or vinegar flies (Drosophila spp.) (Levitan \& Etges 2005, Umina et al. 2005). One of the largest of these studies tracked changes in the genetic structure of D. subobscura populations across multiple continents (Balanyá et al. 2005) with samples collected from Europe, North America and South America over a 24-yr period. They found an increasing frequency of genotypes typical of warm climates in populations of all 3 continents, which corresponded to increasing temperatures over the same time period. Other insect species have also demonstrated genetically controlled phenological traits with climate warming. Bradshaw \& Holzapfel (2001) provided an example of genetic differentiation of a seasonality trait that was consistent with an adaptive evolutionary response to global warming. They reported a genetic change in the photoperiod cue for diapause in populations of the pitcher-plant mosquito Wyeomyia smithii in the northern United States over a 30-yr period that was correlated with increasing temperatures. This genetic adaptation in photoperiod response meant that populations in the northern United States were entering winter diapause $9 \mathrm{~d}$ later, increasing the length of the flight period for the mosquito and closer resembling the photoperiodic response of populations in the warmer southern United States.

\subsection{Evolutionary response in birds}

\subsubsection{Evidence of selection for earlier egg-laying and migration}

A recent review (Dunn \& Winkler 2010) reported that, over a range of 68 species of bird, the majority showed a phenotypically plastic response to egglaying date with changing climate. Half of the species provided evidence for selection on laying date with greater reproductive success for earlier nesting 
individuals. The authors suggested that such climate-induced selection may produce a micro-evolutionary change in phenology but few conclusive examples have been reported in the literature, possibly due to a lack of appropriate long-term data sets, or because the limit of phenotypic plasticity has not yet been reached.

Bradshaw \& Holzapfel (2006) suggested that rapid climate change results in genetic change related to altered seasonal events, such as the timing of the availability of a particular food source. For example, Sparks \& Tryjanowski (2007) suggested that the earlier arrival time of the sand martin Riparia riparia in Britain might be an adaptive response to changes in food supply. Therefore, indirect effects of climate warming should be borne in mind when considering observed phenological changes in bird migration.

There is a lack of knowledge of the molecular genetics of behaviour of phenological traits in birds, which severely restricts our ability to understand evolutionary responses to climate change. However, studies on candidate genes in birds are beginning to help identify specific genes that are associated with migratory behaviour and which vary with geographical location and climate. For example, Mueller et al. (2011) provided evidence for an association between a microsatellite polymorphism in ADCYAP1, a gene that encodes the pituitary adenylate cyclaseactivating polypeptide and migratory behaviour of 14 populations of blackcaps Sylvia atricapilla representing the range of geographical variation in its migration patterns. The polymorphism explained about $2.6 \%$ of the variation in migration tendency among populations and about 2.7 to $3.5 \%$ of variation in migratory restlessness among individuals within 2 independent populations. The multiple functions described for this gene suggest that the gene might act at several levels that all modify the shift between migratory and non-migratory states. However the exact mechanism through which climate influences selection on the gene remains to be established (Mueller et al. 2011).

\subsubsection{Assortative mating}

Assortative mating is the non-random selection of mating partners with respect to one or more traits, it is positive when like phenotypes mate more frequently than would be expected by chance and is negative when the reverse occurs (Hartl \& Jones 2009). A recent study found some evidence of assortative mating in populations of blackcaps in Europe
(Bearhop et al. 2005). In the 1960s, blackcaps that spent their summers in Germany/Austria wintered in Iberia and northern Africa. However, since then, more and more of these birds have begun to overwinter in Britain and Ireland. Thus, a change in migration pattern emerged. This resulted in the birds that spent the winter in Britain and Ireland arriving at their breeding grounds earlier, because critical photoperiods that trigger migration were found to be 10 days earlier than in more southern latitudes. In addition, because of the shorter migratory distance, these birds were possibly in better condition on arrival. The birds that arrived early tended to mate together and chose the best breeding territories, all of which resulted in greater reproductive success. The later-arriving birds also mated together and, therefore, these 2 populations paired assortatively. According to Bearhop et al. (2005), this temporal separation has the potential to promote speciation. Consequently, it may be that changes in environmental conditions that result in new migration routes may lead to the evolution of genetically distinct populations or species. It is therefore likely that, for some birds, future warming that results in earlier arrival times at breeding grounds has the potential to influence speciation, especially if coupled with other factors such as geographical allopatry. While Bearhop et al. (2005) remains an important demonstration of the evolution of a novel migratory pattern and an underlying genetic change, the link to climate requires further investigation (Gienapp et al. 2008, Sheldon 2010).

\subsubsection{Genetic selection for earlier breeding in migrant birds}

The extent to which birds can, and are, tracking changing climatic conditions by altering the timing of reproduction has been explained largely by phenotypic plasticity (Wingfield et al. 1992, Sheldon 2010). However, changing climatic conditions may also be selecting for changes in the frequency of genes that regulate the timing of reproduction in populations. This may allow species to adapt and move past the limits imposed by phenotypic plasticity, though it is possible that the limit/extent of the plasticity response has not yet been reached (Nussey et al. 2005). However, in order for climate-change imposed natural selection to occur, there must be a genetic foundation with sufficient genetic variability between individuals for directional selection of particular traits to take place (Kellermann et al. 2006). 
The degree of plasticity in the timing of reproduction in birds has been shown to be a heritable trait (Nussey et al. 2005, Reed et al. 2008). Selection of this heritable component could allow some individuals to track climatic changes better than others. Selection of these individuals may enable the population to track food resources and reduce phenological mismatches beyond points imposed by current plastic limits (Stenseth \& Mysterud 2002). However, not all species may be able to select for these more plastic individuals. In some species, very little variation in plasticity occurs between individuals in a population (Nussey et al. 2005, Charmantier et al. 2008). This might not be indicative of a total lack of plasticity within the species since populations may be highly plastic in response to a large-scale environmental cue (Reed et al. 2008). For instance, although the timing of breeding in the common guillemot Uria aalge is highly plastic at the population level in response to the NAO, there is very little variation between individuals (Reed et al. 2008). Instead, this lack of an individual response may be because social cues dominate the regulation of the timing of reproduction (Reed et al. 2008). In these species the dominance of sociality may limit an individual's potential response and the possibility for directional selection of a trait (Reed et al. 2008). This will affect the ability of these species to genetically adapt to changing climatic conditions.

In wild bird populations, the genetic components of variance in reproduction dates have been calculated using cross-breeding experiments and models that estimate genetic parameters (Kruuk 2004, Nussey et al. 2005). Using this method, Nussey et al. (2005) concluded that significant genetic variation for laying date plasticity existed in the Dutch Hoge Veluwe great tit population, and that egg-laying date plasticity was significantly heritable. The models used for quantitative genetics enabled an analysis of genetic (co)variances in populations in the wild (Kruuk 2004). This technique relies on parents resembling offspring more closely than randomly sampled individuals from the population. However, closely related individuals are also more likely to experience similar environmental conditions; therefore, variation in the timing of reproduction may appear to be genetically based but instead may be due to environmental conditions. Despite these studies being very convincing, evidence at the DNA level would be useful to confirm that the observed trends in the timing of bird breeding do indeed have a genetic basis and that such trends are not due to parental effects (Kruuk 2004).

Even if some populations or species are tracking climatic changes at the genetic level, this may not be feasible for all populations. For instance, no heritable variation has been shown in the plastic responses of reproduction in collared flycatchers Ficedula albicollis (Brommer et al. 2005). If traits for earlier reproduction are not heritable, selective processes will not be possible. Furthermore, if only a small proportion of individuals carry the genetic traits required for natural selection to occur, there may be insufficient time to allow species to track climatic changes and fitness will be reduced (Nussey et al. 2005). Species that rely on cues that do not reliably indicate changing seasons or physiological requirements are particularly at risk since evolutionary processes may have little or nothing to select upon. For example, migratory bird species, which rely on large-scale climatic patterns may be relying on cues at the wintering ground that no longer match seasonal conditions at the breeding grounds. The capacity for evolutionary change in phenological events may enable some species or populations to reduce potential mismatches and ultimately increase chances of population viability (Stenseth \& Mysterud 2002, Walther et al. 2002). However, it remains to be seen if evolutionary change can occur fast enough to keep pace with the current rate of environmental change (Nussey et al. 2005, Visser 2008).

\section{PHENOLOGICAL ADAPTATION AND SELECTIVE TRAITS IN TREES, INSECTS AND BIRDS}

Regardless of plastic response and genetic adaptation of phenophases, organisms will be subjected to additional selective pressures associated with rising temperature including stress tolerance, competition, and new biotic interactions. A key component in the response of trees will be competition. Dramatic changes in flora compositions occurred as a result of plant colonization from southern refugia following the last glacial retreat (e.g. oak recolonisation, Petit et al. 2002). It is thus highly likely that, with increasing temperatures, European tree populations will be displaced by those from further south or native species will be displaced by exotic invasive species (Simberloff 2000). This could occur over a relatively short time frame, as has been shown with changes in plant and animal abundances in a variety of regions over the past $30 \mathrm{yr}$ (Thomas et al. 2004). The result will be a change in community structure and plant species abundance since some species will diminish and others may become extinct. Thus, short-term responses (perhaps in de- 
cades) will likely be dominated by plasticity, migration and selection of competitive species over others, whereas evolutionary responses might be somewhat delayed (Huntley 2007). Species migration could have significant consequences on 'rear edge' or southern populations (Hampe \& Petit 2005). The southern populations in Europe are often the more diverse populations (e.g. oak; Petit et al. 2002). Thus, if species are being pushed northwards, additional pressure is placed on the southern populations with a risk of considerable loss of genetic diversity within the species (Hampe \& Petit 2005). As such, studies of species at the edge of their range are vital to our understanding of potential evolutionary changes (Crawford 2008).

Some studies have shown genetic variation associated with climate and phenology, but evidence of an evolutionary response to climate change remains scarce (Jump \& Peñuelas 2005, Jump et al. 2006b, 2008, Gienapp et al. 2008). Genetic adaptations other than phenological ones, such as resistance to high temperatures, drought or to climatic fluctuations, will be required and these will interact with phenological traits. So, although we can predict loss in diversity as a consequence of rising temperatures, we cannot predict the nature of evolutionary change in the broad range of genes relevant to environmental change, including changes in disease and other biotic interactions. Studies considering all these traits are required to produce predictive models for climate change impacts on trees.

The ability of the insect species featured in this review to respond via phenotypic plasticity to increasing temperatures appears to be keeping pace with current warming. Populations of the featured species are not reported to be in decline, and evidence for predicted mismatches with other trophic levels has been hard to locate. How these species will respond to additional temperature increases is, however, often unknown, or differs greatly between species (van Asch \& Visser 2007, Forrest \& MillerRushing 2010). Fitness consequences become particularly important when considering insects' interactions with other trophic levels on which their fitness is reliant. While the potential for mismatch with plants appears to be more limited, the potential for mismatch with higher vertebrate trophic levels could be substantial, decreasing predation risks while allowing herbivores and pollinators to remain synchronized with their host plants. Any changes in historic interactions could affect gene frequencies in insect populations, leading to an indirect evolutionary response to climate warming.
It appears that, in different migrant bird species, there is strong evidence indicating that plastic responses have occurred as a consequence of climate warming. However, the rate and magnitude of these changes is both species- and population-specific. Saino et al. (2010) have demonstrated that longdistance migrants experience a greater population decline than short-distance migrants because they experience a larger 'thermal delay' than their shortdistance counterparts. In other words, birds arriving at their breeding site experience a higher temperature (greater number of degree days) now than $50 \mathrm{yr}$ ago with the result that spring phenology (at the breeding site) is more advanced at present. This in turn may cause a greater ecological mismatch for long-distance migrants compared to short-distance migrants.

The timing of arrival at breeding grounds has implications for population success: the earlier arrivals have a better chance of finding a mate and securing the best territory, which as we have seen, can lead to assortative mating. In general, most species are showing a tendency to lay early with no corresponding increase in clutch size, but this may change in future as temperature continues to rise (Dunn \& Winkler 2010). In addition, if annual-and in particular, over-winter-survival is higher because of warmer temperatures, more resident birds can begin to breed earlier, which may result in a depletion of resources by the time migrants arrive.

Pulido (2007) suggested that selection for early arrival and breeding was likely to increase if the trend of increasing temperature persisted. The most likely evolutionary processes leading to a change in migration timing are adaptive changes in migration distance and changes in phenotypic plasticity of departure date in response to day length at the wintering grounds. In addition, over recent decades, climate change has led to a number of heritable genetic changes in bird populations (see Table 1) as a result of both direct and indirect impacts. Evolutionary changes in the timing of migration are likely to involve evolutionary changes in reaction norms, i.e. the framework in which populations or individuals may respond plastically to environmental cues (Pulido 2007, Tøttrup et al. 2010).

\section{CONCLUSIONS}

Important questions are how species are going to survive in a warming world, and whether phenotypic plasticity will be sufficient to ensure population per- 
sistence, or if some kind of genetic response is inevitable. The short answer - based on the evidence accumulated in this review - is that in the shortterm, both long- and short-lived species appear to be responding to current warming by means of phenotypic plasticity, but over the longer term, selection for fitness traits will be necessary to ensure continued survival in a warmer world.

A phenotypically plastic response to climate warming has been demonstrated in all species reviewed here, but this factor may be more important in longlived species than species with a shorter life-span, which have the ability to evolve rapidly and therefore have greater potential to genetically adapt to changing environmental conditions (Sheldon 2010). Phenotypic plasticity allows organisms to respond to changing environments, but if the new environment differs too greatly, plastic responses may result that are more mal-adaptive (Price et al. 2003). These maladaptive responses may reduce the fitness of an organism and reduce the chances of population persistence. However, if the population persists despite the mal-adaptation, selection pressures could lead to evolutionary change including a change in the plastic limits of the species. Our ability to predict how phenology will evolve in response to future climate warming remains limited (Forrest \& Miller-Rushing 2010). For example, warming may result in earlier bud burst, but if damage from late frost persists, selection may act in favour of later bud burst in order to avoid injury (Forrest \& Miller-Rushing 2010). Furthermore, phenotypic responses may be misinterpreted as changes in mean trait values of a population, and therefore care must be taken when reporting the underlying mechanisms causing the observed change (Gienapp et al. 2008, Husby et al. 2010).

Whereas many recent studies have reported changes in phenology and genetic adaptation (Table 1) attributed to climate change, they have been largely based on single species at specific locations, using a range of analytical techniques (Dunn \& Winkler 2010, Lehikoinen \& Sparks 2010). However, in order to make reliable and meaningful predictions of the impact of future climate change on phenology, a more standardized approach over large geographical areas (particularly for migrating species) and across a range of trophic levels could greatly improve our understanding of the impact of future climate change on plant and animal species (as concluded by Dunn \& Winkler 2010 and Lehikoinen \& Sparks 2010). The recent establishment of citizen science networks, which request members of the general public to re- cord phenological observations, has become a popular way of obtaining useful data on a range of plant and animal species over large geographical areas. Recently, Beaubien \& Hamann (2011) have demonstrated the effectiveness of such networks in providing scientific data through an evaluation of the PlantWatch network in Canada. Other such citizen science networks have been established in, for example, the USA, the UK, the Netherlands, Ireland, etc. primarily as a tool to demonstrate the impact of climate change on local plant and animal life. These networks, if run effectively and using standard protocols, have the potential to provide useful scientific data on a wide range of plant and animal species covering extensive geographical areas, which could not be covered by a few scientists alone.

To date many of the evolutionary responses reported as resulting from climate warming are speculative rather than being strongly supported by empirical data (Jonzén et al. 2007, Gienapp et al. 2008). This is not to say that evolutionary change, in response to recent warming, has not already occurred or will not occur in the future, but just that sufficient evidence has not been acquired (Sheldon 2010). It was not surprising that we found more evidence, in the literature, for a phenotypically plastic response to climate warming than for a genetic response, since these mechanisms work on different timescales. Nonetheless, there was at least some speculation in the literature that climate-driven genetic adaptation is likely to be revealed in the future in all groups whether they are long- or short-lived species. Since absence of evidence is not evidence of absence, we therefore look forward to seeing conclusive reports of genetic responses to climate warming in future.

\subsection{Knowledge gaps and future research}

The impact of future increases in temperature on phenology is complex and difficult to predict. One area that appears to lack information is the nature of and the boundaries of phenotypic plasticity. Therefore, it would be useful to demonstrate and quantify experimentally the plastic limits of key phenological events of a range of organisms in response to warming. This in turn would help identify how and when such limits may be reached and allow mitigating measures to be implemented as necessary. It was also clear from the review that current models require more data upon which to accurately predict the impact of further warming on trees, insects and birds. In particular, in agreement with Caffarra \& Eccel 
Table 1. Reported phenotypic plasticity and evolutionary adaptation in trees, insects and birds to spring warming associated with climate change

\begin{tabular}{|c|c|c|}
\hline & Plastic response & Evolutionary response \\
\hline \multirow[t]{2}{*}{ Trees } & \multirow{2}{*}{$\begin{array}{l}\text { Earlier bud burst, earlier flowering and increased } \\
\text { growing season length } \\
\text { (Menzel \& Fabian 1999, Peñuelas \& Filella 2001, } \\
\text { Donnelly et al. 2006, Menzel et al. 2006, } \\
\text { Alizoti et al. 2010, Askeyev et al. 2010) }\end{array}$} & $\begin{array}{l}\text { Change in gene frequency } \\
\text { (Jump et al. 2006a) }\end{array}$ \\
\hline & & $\begin{array}{l}\text { Epigenetic effects on bud phenology } \\
\text { (Johnsen et al. 2005, Yakovlev et al. 2006, 2011) }\end{array}$ \\
\hline \multirow[t]{3}{*}{ Insects } & $\begin{array}{l}\text { Earlier emergence } \\
\text { (Morris 2000, Roy \& Sparks 2000, } \\
\text { Stefanescu et al. 2003, Gordo \& Sanz 2005, } \\
\text { Hassall et al. 2007, Dingemanse \& Kalkman 2008, } \\
\text { Altermatt 2010, Sparks et al. 2010, } \\
\text { Westwood \& Blair 2010) }\end{array}$ & \multirow[t]{3}{*}{$\begin{array}{l}\text { Change in gene frequency } \\
\text { (Bradshaw \& Holzapfel 2001, Levitan \& Etges 2005 } \\
\text { Umina et al. 2005, Balanyá et al. 2006) }\end{array}$} \\
\hline & $\begin{array}{l}\text { Earlier migratory activity } \\
\text { (Zhou et al. 1995, Harrington et al. 2007) }\end{array}$ & \\
\hline & $\begin{array}{l}\text { Increased number of generations per season } \\
\text { (Altermatt 2010, Martín-Vertedor et al. 2010) }\end{array}$ & \\
\hline \multirow[t]{6}{*}{ Birds } & \multirow{2}{*}{$\begin{array}{l}\text { Earlier arrival } \\
\text { (Butler 2003, Cotton 2003, } \\
\text { Hüppop \& Hüppop 2003, Lehikoinen et al. 2004, } \\
\text { Sparks et al. 2005, Møller et al. 2008, Saino \& } \\
\text { Ambrosini 2008, Donnelly et al. 2009, } \\
\text { Askeyev et al. 2010, Lehikoinen \& Sparks 2010, } \\
\text { Saino et al. 2010) }\end{array}$} & $\begin{array}{l}\text { Assortative mating } \\
\text { (Bearhop et al. 2005) }\end{array}$ \\
\hline & & \multirow[t]{5}{*}{$\begin{array}{l}\text { Earlier arrival } \\
\text { (Jonzén et al. 2006, Sparks \& Tryjanowski 2007) }\end{array}$} \\
\hline & $\begin{array}{l}\text { Later arrival } \\
\text { (Barrett 2002, Peñuelas et al. 2002) }\end{array}$ & \\
\hline & $\begin{array}{l}\text { Earlier egg laying } \\
\text { (Crick \& Sparks 1999, Both \& Visser 2001, } \\
\text { Both et al. 2006, Both \& te Marvelde 2007, } \\
\text { Møller et al. 2008, Dunn \& Winkler 2010, } \\
\text { Matthysen et al. 2011) }\end{array}$ & \\
\hline & $\begin{array}{l}\text { Asynchrony with food source } \\
\text { (Visser et al. 1998, Both et al. 2005, } \\
\text { Sparks \& Tryjanowski 2007) }\end{array}$ & \\
\hline & $\begin{array}{l}\text { Synchrony with food source } \\
\text { (Charmantier et al. 2008, Matthysen et al. 2011) }\end{array}$ & \\
\hline
\end{tabular}

(2010), data (experimental or observed) on species' response to climate extremes would provide useful information for the development of general predictive models.

In order to gain further insight into the mechanisms underlying genetic adaptation to climate warming, it will be crucial to identify the genetic and epigenetic basis of phenological traits. Furthermore, it would be also useful to identify appropriate long-term data sets and/or establish new data sets that would help in the search for an evolutionary response to warming.

Acknowledgements. The authors are grateful to the Irish Environmental Protection Agency (EPA) for providing financial assistance for this work, under the STRIVE programme, project number 2007-CCRP-2.4, Climate change impacts on phenology: implications for terrestrial ecosystems. In addition, we thank the anonymous reviewers for their valuable suggestions and useful comments on an earlier draft of this manuscript.

\section{LITERATURE CITED}

Ahas R (1999) Long-term phyto-ornitho and ictyophenological time-series analyses in Estonia. Int J Biometeorol 42: 119-123

Aitken SN, Yeaman S, Holliday JA, Wang T, Curtis-McLane S (2008) Adaptation, migration or extirpation: climate change outcomes for tree populations. Evol Appl 1:95-111

Alizoti K, Kilimis P, Gallios PG (2010) Temporal and spatial variation of flowering among Pinus nigra Arn clones under changing climatic conditions. For Ecol Manag 259: 786-797 
Altermatt F (2010) Climatic warming increases voltinism in European butterflies and moths. Proc Biol Sci 277: 1281-1287

Askeyev OV, Sparks TH, Askeyev IV, Tishin DV, Tryjanowski P (2010) East versus west: contrasts in phenological patterns. Glob Ecol Biogeogr 19:783-793

> Augspurger CK, Bartlett EA (2003) Differences in leaf phenology between juvenile and adult trees in a temperate deciduous forest. Tree Physiol 23:517-525

Balanyá J, Oller JM, Huey RB, Gilchrist GW, Serra L (2006) Global genetic change tracks global climate warming in Drosophilia subobscura. Science 313:1773-1775

Barrett RT (2002) The phenology of spring bird migration to north Norway. Bird Study 49:270-277

Bearhop S, Fiedler W, Furness RW, Votier SC and others (2005) Assortative mating as a mechanism for rapid evolution of a migratory divide. Science 310:502-504

Beaubien EG, Hamann A (2011) Plant phenology networks of citizen scientists: recommendations from two decades of experience in Canada. Int J Biometeorol 55:833-841

Beebee TJC (1995) Amphibian breeding and climate. Nature 374:219-220

> Bennett KD, Tzedakis PC, Willis KJ (1991) Quaternary refugia of north European trees. J Biogeogr 18:103-115

Böhlenius $\mathrm{H}$, Huang $\mathrm{T}$, Charbonnel-Campaa L, Brunner AM, Jansson S, Strauss SH, Nilsson O (2006) The conserved CO/FT regulatory module controls timing of flowering and seasonal growth cessation in trees. Science 312:1040-1043

Both C (2010) Food availability, mistiming and climatic. In: Møller AP, Fiedler W, Berthold P (eds) Effects of climate change on birds. Oxford University Press, London, p 129-148

Both C, te Marvelde L (2007) Climate change and timing of avian breeding and migration through Europe. Clim Res 35:93-105

Both C, Visser M (2001) Adjustment to climate change is constrained by arrival date in a long-distance migrant bird. Nature 411:296-298

Both C, Bijlsma RG, Visser M (2005) Climatic effects on timing of spring migration and breeding in a long-distance migrant, the pied flycatcher Ficedula hypoleuca. J Avian Biol 36:368-373

Both C, Bouwhius S, Lessells CM, Visser ME (2006) Climate change and population declines in a long-distance migratory bird. Nature 441:81-83

Bradshaw AD (1965) Evolutionary significance of phenotypic plasticity in plants. Adv Genet 13:115-155

Bradshaw AD (1972) Some of the evolutionary consequences of being a plant. Evol Biol 5:25-47

Bradshaw WE, Holzapfel CM (2001) Genetic shift in photoperiodic response correlated with global warming. Proc Natl Acad Sci USA 98:14509-14511

Bradshaw WE, Holzapfel CM (2006) Evolutionary response to rapid climate change. Science 312:1477-1478

Bradshaw HD Jr, Stettler RF (1995) Molecular genetics of growth and development in Populus IV Mapping QTLs with large effects on growth, form, and phenology traits in a forest tree. Genetics 139:963-973

Brommer JE, Merilä J, Sheldon BC, Gustafsson L (2005) Natural selection and genetic variation for reproductive reaction norms in a wild bird population. Evolution 59: 1362-1371

Butler CJ (2003) The disproportionate effect of global warming on the arrival dates of short-distance migratory birds in North America. Ibis 145:484-495

Caffarra A, Eccel E (2010) Increasing the robustness of phenological models for Vitis vinifera $\mathrm{CV}$, Chardonnay. Int J Biometeorol 54:255-267

Caffarra A, Donnelly A (2011) The ecological significance of phenology in four different tree species: effects of light and temperature on bud burst. Int $\mathrm{J}$ Biometeorol 55: 711-721

Caffarra A, Donnelly A, Chuine I (2011) Modelling the timing of budburst of Betula pubescens budburst. II. Integrating complex effects of photoperiod into processbased models of budburst. Clim Res 46(2):159-170

Cannell MGR, Smith RI (1983) Thermal time, chill days and prediction of budburst in Picea-Sitchensis. J Appl Ecol 20:951-963

Charmantier A, McCleery RH, Cole LR, Perrins C, Kruuk LEB, Sheldon BC (2008) Adaptive phenotypic plasticity in response to climate change in a wild bird population. Science 320:800-803

Chmielewski FM, Rötzer T (2001) Responses of tree phenology to climatic changes across Europe. Agric For Meteorol 108:101-112

Cleland EE, Chuine I, Menzel A, Mooney HA, Schwartz MD (2007) Shifting plant phenology in response to global change. Trends Ecol Evol 22:357-365

Cotton PA (2003) Avian migration phenology and global climate change. Proc Natl Acad Sci USA 100:12219-12222

Crawford RMM (2008) Plants at the margin: ecological limits and climate change. Cambridge University Press, Cambridge

> Crick HQP, Sparks TH (1999) Climate change related to egg-laying trends. Nature 399:423-424

> Derory J, Scotti-Saintagne C, Bertocchi E, Le Dantec L and others (2010) Contrasting relations between diversity of candidate genes and variation of bud burst in natural and segregating populations of European oaks. Heredity 105: 401-411

> Dingemanse NJ, Kalkman VJ (2008) Changing temperature regimes have advanced the phenology of Odonata in the Netherlands. Ecol Entomol 33:394-402

Doi H (2008) Delayed phenological timing of dragonfly emergence in Japan over five decades. Biol Lett 4: 388-391

Donnelly A, Salamin N, Jones MB (2006) Changes in tree phenology: an indicator of spring warming in Ireland? Biol Environ 106:47-55

> Donnelly A, Cooney T, Jennings E, Buscardo E, Jones MB (2009) Response of birds to climatic variability, evidence from the western fringe of Europe. Int J Biometeorol 53: 211-220

> Dose V, Menzel A (2004) Bayesian analysis of climate change impacts in phenology. Glob Change Biol 10: 259-272

> Dounavi A, Koutsias N, Ziehe M, Hattemer H (2010) Spatial patterns and genetic structures within beech populations (Fagus sylvatica L.) of forked and non-forked individuals. Eur J For Res 129:1191-1202

Dunn PO, Winkler DW (2010) Effects of climate change on timing of breeding and reproductive success in birds. In: Møller AP, Fiedler W, Berthold P (eds) Effects of climate change on birds. Oxford University Press, London, p 113-128

> Dunne JA, Harte J, Taylor KJ (2003) Subalpine meadow flowering phenology responses to climate change: integrating experimental and gradient methods. Ecol Monogr 73:69-86

Ferreira V, Gonçalves AL, Godbold DL, Canhoto C (2010) Effect of increased atmospheric $\mathrm{CO}_{2}$ on the performance of an aquatic detritivore through changes in water tem- 
perature and litter quality. Glob Change Biol 16: 3284-3296

Fitter AH, Fitter RSR (2002) Rapid changes in flowering time in British plants. Science 296:1689-1691

- Fonti P, von Arx G, García-González I, Eilmann B, SassKlaassen U, Gärtner H, Eckstein D (2010) Studying global change through investigation of the plastic responses of xylem anatomy in tree rings. New Phytol 185:42-53

Forrest J, Miller-Rushing AJ (2010) Toward a synthetic understanding of the role of phenology in ecology and evolution. Philos Trans R Soc Lond B Biol Sci 365: 3101-3112

- Garcia-Gil MR, Mikkonen M, Savolainen O (2003) Nucleotide diversity at two phytochrome loci along a latitudinal cline in Pinus sylvestris. Mol Ecol 12:1195-1206

Genner MJ, Halliday NC, Simpson SD, Southward AJ, Hawkins SJ, Sims DW (2010) Temperature-driven phenological changes within a marine larval fish assemblage. J Plankton Res 32:699-708

C Gienapp P, Teplitsky C, Alho JS, Mills AJ, Merilä J (2008) Climate change and evolution: disentangling environmental and genetic responses. Mol Ecol 17:167-178

Gordo O, Sanz JJ (2005) Phenology and climate change: a long-term study in a Mediterranean locality. Oecologia 146:484-495

> Guo K, Hao SG, Sun OJ, Kang L (2009) Differential responses to warming and increased precipitation among three contrasting grasshopper species. Glob Change Biol 15: 2539-2548

> Gutschick VP, BassiriRad H (2003) Extreme events as shaping physiology, ecology, and evolution of plants: toward a unified definition and evaluation of their consequences. New Phytol 160:21-42

Hall D, Luquez V, Garcia VM, St Onge KR, Jansson S, Ingvarsson PK (2007) Adaptive population differentiation in phenology across a latitudinal gradient in European aspen (Populus tremula, L): a comparison of neutral markers, candidate genes and phenotypic traits. Evolution 61:2849-2860

> Hampe A, Petit RJ (2005) Conserving biodiversity under climate change: the rear edge matters. Ecol Lett 8:461-467

Harrington R, Clark SJ, Welham SJ, Verrier PJ and others (2007) Environmental change and the phenology of European aphids. Glob Change Biol 13:1550-1564

Hartl DL, Jones EW (2009) Genetics, analysis of genes and genomes, 7th ed. Jones and Bartlett, Boston, MA

- Hassall C, Thompson DJ, French GC, Harvey IF (2007) Historical changes in the phenology of British Odonata are related to climate. Glob Change Biol 13:933-941

Hegland SJ, Nielsen A, Lázaro A, Bjerknes A, Totland $\varnothing$ (2009) How does climate warming affect plant-pollinator interactions? Ecol Lett 12:184-195

Heide OM (2003) High autumn temperature delays spring bud burst in boreal trees, counterbalancing the effect of climatic warming. Tree Physiol 23:931-936

Hodkinson TR (2011) Integrating ecology and systematics in climate change research In: Hodkinson TR, Jones MB, Waldren S, Parnell JAN (eds) Climate change ecology and systematics. The systematics association special series. Cambridge University Press, Cambridge, p 3-43

Hullé $M$, d'Acier AC, Bankhead-Dronnet S, Harrington R (2010) Aphids in the face of global changes. C R Biol 333: 497-503

> Huntley B (2007) Evolutionary response to climate change? Heredity 98:247-248

Hüppop O, Hüppop K (2003) North Atlantic Oscillation and timing of spring migration in birds. Proc R Soc Lond B Biol Sci 270:233-240

Hurrell JW, Trenberth KE (2010) Climate change. In: Møller AP, Fiedler W, Berthold P (eds) Effects of climate change on birds. Oxford University Press, London, p 9-29

Husby A, Nussey DH, Visser ME, Wilson AJ, Sheldon BC, Kruuk LEB (2010) Contrasting patterns of phenotypic plasticity in reproductive traits in two great tit (Parus major) populations. Evolution 64-68:2221-2237

Ingvarsson PK, García MV, Hall D, Luquez V, Jansson S (2006) Clinal variation in phyB2, a candidate gene for day-length-induced growth cessation and bud set, across a latitudinal gradient in European aspen (Populus tremula). Genetics 172:1845-1853

Inouye DW, Barr B, Armitage KB, Inouye BD (2000) Climate change is affecting altitudinal migrants and hibernating species. Proc Natl Acad Sci USA 97:1630-1633

Jalas J, Suominen J (1976) Atlas Florae Europaeae: distribution of vascular plants in Europe. The Committee for Mapping the Flora of Europe and Societas Biologica Fennica Vanamo, Helsinki

Johnsen O, Dæhlen OG, Østreng G, Skrøppa T (2005) Daylength and temperature during seed production interactively affect adaptive performance of Picea abies progenies. New Phytol 168:589-596

Jonzén N, Lindén A, Ergon T, Knudsen E and others (2006) Rapid advance of spring arrival dates in long-distance migratory birds. Science 312:1959-1961

> Jonzén NA, Ergon T, Lindén A, Strenseth NC (2007) Bird migration and climate: the general picture and beyond. Clim Res 35:177-180

Jump AS, Peñuelas J (2005) Running to stand still: adaptation and the response of plants to rapid climate change. Ecol Lett 8:1010-1020

Jump A, Hunt J, Peñuelas J (2006a) Rapid climate changerelated growth decline at the southern range edge of Fagus sylvatica. Glob Change Biol 12:2163-2174

> Jump AS, Hunt JM, Martinez-Izquierdo JA, Peñuelas J (2006b) Natural selection and climate change: temperature-linked spatial and temporal trends in gene frequency in Fagus sylvatica. Mol Ecol 15:3469-3480

Jump AS, Peñuelas J, Rico L, Ramallo E, Estiarte M, Martinez-Izquierdo JA, Lloret F (2008) Simulated climate change provokes rapid genetic change in the Mediterranean shrub Fumana thymifolia. Glob Change Biol 14: $637-643$

Karell P, Ahola K, Karstinen T, Valkama J, Brommer JE (2011) Climate change drives microevolution in a wild bird. Nat Commun 2:208 doi:10.1038/ncomms1213

Kellermann VM, van Heerwaarden B, Hoffmann AA, Sgrò CM (2006) Very low additive genetic variance and evolutionary potential in multiple populations of two rainforest Drosophila species. Evolution 60:1104-1108

Kocmánková E, Trnka M, Eitzinger J, Formayer H and others (2010) Estimating the impact of climate change on the occurrence of selected pests in the Central European region. Clim Res 44:95-105

Körner C, Basler D (2010) Phenology under global warming. Science 327:1461-1462

Kramer K (1995) Phenotypic plasticity of the phenology of seven species in relation to climatic warming. Plant Cell Environ 18:93-104

Kreyling J, Thiel D, Nagy L, Jentsch A, Huber G, Konnert M, Beierkuhnlein C (2012) Late frost sensitivity of juvenile Fagus sylvatica L. differs between southern Germany and Bulgaria and depends on preceding air temperature. Eur J For Res 131:717-725 
Kruuk LEB (2004) Estimating genetic parameters in natural populations using the 'animal model'. Philos Trans R Soc Lond B Biol Sci 359:873-890

Lechowicz MJ (1984) Why do temperate deciduous trees leaf out at different times? Adaptation and ecology of forest communities. Am Nat 124:821-842

Lehikoinen E, Sparks TH (2010) Changes in migration. In: Møller AP, Fiedler W, Berthold P (eds) Effects of climate change on birds. Oxford University Press, London, p 89-112

Lehikoinen E, Sparks TH, Zalakevicius M (2004) Arrival and departure dates. In: Møller AP, Fiedler W, Berthold P (eds) Effects of climate change on birds. Oxford University Press, London, p 1-31

Levitan M, Etges WJ (2005) Climate change and recent genetic flux in populations of Drosophila robusta. BMC Evol Biol 5:4 doi:101186/1471-2148-5-4

Luedeling E, Steinmann KP, Zhang M, Brown PH, Grant J, Girvetz EH (2011) Climate change effects on walnut pests in California. Glob Change Biol 17:228-238

- Martín-Vertedor D, Ferrero-García JJ, Torres-Vila LM (2010) Global warming affects phenology and voltinism of Lobesia botrana in Spain. Agric For Entomol 12:169-176

Matthysen E, Adriaensen F, Dhondt AA (2011) Multiple responses to increasing spring temperatures in the breeding cycle of blue and great tits (Cyanistes caeruleus, Parus major). Glob Change Biol 17:1-6

McDowell N, Pockman WT, Allen CD, Breshears DD and others (2008) Mechanisms of plant survival and mortality during drought: Why do some plants survive while others succumb to drought? New Phytol 178:719-739

> Menzel A (2000) Trends in phenological phases in Europe between 1951 and 1996. Int J Biometeorol 44:76-81

> Menzel A, Fabian P (1999) Growing season extended in Europe. Nature 397:659

> Menzel A, Estrella N, Fabian P (2001) Spatial and temporal variability of the phenological seasons in Germany from 1951 to 1996. Glob Change Biol 7:657-666

Menzel A, Sparks TH, Estrella N, Koch E and others (2006) European phenological response to climate change matches the warming pattern. Glob Change Biol 12: 1969-1976

Mitchell FJG (2006) Where did Ireland's trees come from? Biol Environ 106B:251-259

Møller AP, Rubolini D, Lehikoinen E (2008) Populations of migratory bird species that did not show a phenological response to climate change are declining. Proc Natl Acad Sci USA 105:16195-16200

Monteith KL, Bleich TR, Stephenson TR, Pierce BM, Conner MM, Klaver RW, Bowyer RT (2011) Timing of seasonal migration in mule deer: effects of climate, plant phenology and life-history characteristics. Ecosphere 2:art47 doi:10.1890/ES10-00096.1

Morin X, Roy J, Sonié L, Chuine I (2010) Changes in leaf phenology of three European oak species in response to experimental climate change. New Phytol 186:900-910

Morris RKA (2000) Shifts in the phenology of hoverflies in Surrey: Do these reflect the effects of global warming? Dipterists Digest 7:103-108

Moyes K, Nussey DH, Clements MN, Guinness FE and others (2011) Advancing breeding phenology in response to environmental change in a wild red deer population. Glob Change Biol 17:2455-2469

Mueller JC, Pulido F, Kempenaers B (2011) Identification of a gene associated with avian migratory behaviour. Proc Biol Sci 278(1719):2848-2856

Müller-Starck G, Haas J, Ziehe M (2010) Genetic response of juvenile plants to translocation along an altitudinal gradient: a case study with Larix europaea und Pinus mugo. Forstarchiv 81:142-145

Musolin (2009) Too hot to handle? Phenological and life-history responses to simulated climate change of the southern green stink bug Nezara viridula (Heteroptera: Pentatomidae). Glob Change Biol 16:73-87

Neale DB, Savolainen O (2004) Association genetics of complex traits in conifers. Trends Plant Sci 9:325-330

Nussey DH, Postma E, Gienapp P, Visser ME (2005) Selection on heritable phenotypic plasticity in a wild bird population. Science 310:304-306

Ogaya R, Peñuelas J (2007) Tree growth, mortality, and above-ground biomass accumulation in a holm oak forest under a five-year experimental field drought. Plant Ecol 189:291-299

> Parmesan C (2006) Ecological and evolutionary responses to recent climate change. Annu Rev Ecol Evol Syst 37: $637-669$

> Peñuelas J, Filella I (2001) Responses to a warming world. Science 294:793-795

> Peñuelas J, Filella I, Comas P (2002) Changed plant and animal life cycles from 1952-2000 in the Mediterranean region. Glob Change Biol 8:531-544

> Peñuelas J, Ogaya R, Boada M, Jump A (2007) Migration, invasion and decline: changes in recruitment and forest structure in a warming-linked shift of European beech forest in Catalonia. Ecography 30:829-837

Peñuelas J, Hunt J, Ogaya R, Jump A (2008) Twentieth century changes of tree-ring $\delta 13 \mathrm{C}$ at the southern rangeedge of Fagus sylvatica: increasing water-use efficiency does not avoid the growth decline induced by warming at low altitudes. Glob Change Biol 14:1076-1088

> Peñuelas J, Canadell J, Ogaya R (2011) Increased water-use efficiency during the 20th century did not translate into enhanced tree-growth. Glob Ecol Biogeogr 20:597-608

Petit RJ, Brewer S, Bordács S, Burg K and others (2002) Identification of refugia and postglacial colonisation routes of European white oaks based on chloroplast DNA and fossil pollen evidence. For Ecol Manage 156:49-74

> Pigliucci M, Murren CJ, Schlichting CD (2006) Phenotypic plasticity and evolution by genetic assimilation. J Exp Biol 209:2362-2367

Post E, Forchhammer MC (2008) Climate change reduces reproductive success of an Arctic herbivore through trophic mismatch. Philos Trans R Soc B 363:2367-2373

Price TD, Qvarnstrom A, Irwin DE (2003) The role of phenotypic plasticity in driving genetic evolution. Proc R Soc Lond B 270:1433-1440

Pulido F (2007) Phenotypic changes in spring arrival: evolution, phenotypic plasticity, effects of weather and condition. Clim Res 35:5-23

Pulido F, Berthold P, Mohr G, Querner U (2001) Heritability of the timing of autumn migration in a natural bird population. Proc R Soc Lond B 268:953-959

> Reed TE, Kruuk LE, Wanless S, Frederiksen M, Cunningham EJ, Harris MP (2008) Reproductive senescence in a long-lived seabird: rates of decline in late-life performance are associated with varying costs of early reproduction. Am Nat 171:89-101

Roy DB, Sparks TH (2000) Phenology of British butterflies and climate change. Glob Change Biol 6:407-416

$>$ Rutishauser T, Schleip C, Sparks TH, Nordli Ø and others (2009) Temperature sensitivity of Swiss and British plant phenology 1753-1958. Clim Res 39:179-190

- Saino N, Ambrosini R (2008) Climatic connectivity between Africa and Europe may serve as a basis for phenotypic 
adjustment of migration schedules of trans-Saharan migratory birds. Glob Change Biol 14:250-263

Saino N, Ambrosini R, Rubolini D, von Hardenberg J and others (2010) Climate warming, ecological mismatch at arrival and population decline in migratory birds. Proc $\mathrm{R}$ Soc Lond B Biol Sci 10:1-8

Sánchez-Vargas NM, Sánchez L, Rozenberg P (2007) Plastic adaptive response to weather events: a pilot study in a maritime pine tree ring. Can J Res 37:2090-2095

Sarvas R (1974) Investigations on the annual cycle of development of forest trees. II. Autumn dormancy and winter dormancy. Commun Inst Forestalis Fenniae 84:1-101

Savolainen O, Pyhäjärvi T (2007) Genomic diversity in forest trees. Curr Opin Plant Biol 10:162-167

Savolainen O, Pyhäjärvi T, Knürr T (2007) Gene flow and local adaptation in trees. Annu Rev Ecol Evol Syst 38: 595-619

Schleip C, Menzel A, Dose V (2008) Norway spruce (Picea abies): Bayesian analysis of the relationship between temperature and bud burst. Agric Meteorol 148:631-643

Schleip C, Rais A, Menzel A (2009a) Bayesian analysis of temperature sensitivity of plant phenology in Germany. Agric Meteorol 149:1699-1708

Schleip C, Sparks T, Estrella N, Menzel A (2009b) Spatial variation in onset dates and trends in phenology across Europe. Clim Res 39:249-260

Scoble MJ (1995) The Lepidoptera: form, function and diversity. Oxford University Press, London

Sheldon BC (2010) Genetic perspectives on the evolutionary consequences of climate change in birds. In: Møller AP, Fiedler W, Berthold P (eds) Effects of climate change on birds. Oxford University Press, London, p 149-168

Simberloff D (2000) Global climate change and introduced species in United States forests. Sci Total Environ 262: 253-261

Sims DW, Wearmouth VJ, Genner MJ, Southward AJ, Hawkins SJ (2004) Low-temperature-driven early spawning migration of a temperate marine fish. J Anim Ecol 73:333-341

Sparks TH, Jeffree EP, Jeffree CE (2000) An examination of the relationship between flowering times and temperature at the national scale using long-term phenological records from the UK. Int J Biometeorol 44:82-87

Sparks TH, Tryjanowski P (2007) Patterns of spring arrival dates differ in two hirundines. Clim Res 35:159-164

Sparks TH, Bairlein F, Bojarinova JG, Huppop O and others (2005) Examining the total arrival distribution of migratory birds. Glob Change Biol 11:22-30

Sparks TH, Langowska A, Głazaczow A, Wilkaniec Z, Bie kowska M, Tryjanowski P (2010) Advances in the timing of spring cleaning by the honeybee Apis mellifera in Poland. Ecol Entomol 35:788-791

Stefanescu C, Peñuelas J, Filella I (2003) Effects of climatic change on the phenology of butterflies in the northwest Mediterranean Basin. Glob Change Biol 9:1494-1506

Stenseth NC, Mysterud A (2002) Climate, changing phenology, and other life history traits: non-linearity and match-

Editorial responsibility: Nils Chr. Stenseth, Oslo, Norway mismatch to the environment. Proc Natl Acad Sci USA 99:13379-13381

Thomas CD, Cameron A, Green RE, Bakkenes M and others (2004) Extinction risk from climate change. Nature 427: 145-148

Thomasset M, Fernández-Manjarrés JF, Douglas GC, Frascaria-Lacoste N, Hodkinson TR (2011) Hybridisation, introgression and climate change: a case study for the tree genus Fraxinus (Oleaceae). In: Hodkinson TR, Jones MB, Waldren S, Parnell JAN (eds) Climate change ecology and systematics. Systematics Association Special Series Volume 78, Cambridge University Press, Cambridge, p 320-342

Tøttrup AP, Rainio K, Coppack T, Lehikoinen E, Rahbek C, Thorup K (2010) Local temperature fine-tunes the timing of spring migration in birds. Integr Comp Biol 50: 293-304

Umina PA, Weeks AR, Kearney MR, McKechnie SW, Hoffmann AA (2005) A rapid shift in classical clinal pattern in Drosophila reflecting climate change. Science 308: 691-693

> Vähätalo AV, Rainio K, Lehikoinen A, Lehikoinen E (2004) Spring arrival of birds depends on the North Atlantic Oscillation. J Avian Biol 35:210-216

> van Asch M, Visser ME (2007) Phenology of forest caterpillars and their host trees: the importance of synchrony. Annu Rev Entomol 52:37-55

Visser ME (2008) Keeping up with a warming world, assessing the rate of adaptation to climate change. Proc R Soc Lond B 275:649-659

Visser ME, van Noordwij AJ, Tinbergen JM, Lessells CM (1998) Warmer springs lead to mistimed reproduction in great tits (Parus major). Proc R Soc Lond B Biol Sci 265: $1867-1870$

Vitasse Y, Bresson CC, Kremer A, Michalet R, Delzon S (2010) Quantifying phenological plasticity to temperature in two temperate tree species. Funct Ecol 24:1211-1218

Walther GR, Post E, Convey P, Menzel A and others (2002) Ecological responses to recent climate change. Nature 416:389-395

Westwood AR, Blair D (2010) Effect of regional climate warming on the phenology of butterflies in boreal forests in Manitoba, Canada. Environ Entomol 39:1122-1133

Wingfield JC, Hahn TP, Levin R, Honey P (1992) Environmental predictability and control of gonadal cycles in birds. J Exp Zool 261:214-231

Yakovlev IA, Fossdal CG, Johnsen O, Junttila O, Skrøppa T (2006) Analysis of gene expression during bud burst initiation in Norway spruce via ESTs from subtracted cDNA libraries. Tree Genet Genomes 2:39-52

Yakovlev IA, Assante DKA, Fossdal CG, Junttila O, Johnsen O (2011) Differential gene expression related to an epigenetic memory affecting climatic adaptation in Norway spruce. Plant Sci 180:132-139

Zhou X, Harrington R, Woiwod IP, Perry JN, Bale JS, Clark SJ (1995) Effects of temperature on aphid phenology. Glob Change Biol 1:303-313

Submitted: August 23, 2011; Accepted: March 16, 2012

Proofs received from author(s): June 29, 2012 